Pak. j. sci. ind. res. Ser. B: biol. sci. 201255 (2) 93-100

\title{
Determination of Lead and Cadmium in Hen Eggs by Graphite France Electrothermal Atomic Absorption Spectrometry and Estimation of the Daily Intake
}

\author{
Ishratullah Siddiqui ${ }^{\mathrm{a} *}$, Shaikh Sirajuddin Nizami ${ }^{\mathrm{b}}$, Farooq Ahmed Khan ${ }^{\mathrm{a}}$, Durdana Rais Hashmi ${ }^{\mathrm{a}}$, \\ Uzma Rashid $^{a}$, Alia Bano Munshi ${ }^{\mathrm{a}}$ and Shah Ali-Ul-Qadar ${ }^{\mathrm{c}}$ \\ ${ }^{a}$ PCSIR Laboratories Complex Karachi, Shahrah-e-Dr. Salimuzzaman Siddiqui, Karachi-75280, Pakistan \\ ${ }^{b}$ Department of Chemistry, University of Karachi, Karachi-75270, Pakistan \\ 'Department of Karachi Institute of Biotechnology and Genetic Engineering (KIBGE), \\ University of Karachi, Karachi-75270, Pakistan
}

(received June 9, 2011; revised September 9, 2011; accepted September 24, 2011)

\begin{abstract}
A total of 54 hen eggs were procured from nine poultry farms of Sindh, Pakistan in different batches to determine lead and cadmium toxicity. The quantitative analysis of lead $(\mathrm{Pb})$ and cadmium $(\mathrm{Cd})$ in egg samples were performed on electrothermal atomic absorption spectrometer (ETAAS), with Zeeman effects background correction. Lead concentrations in hen egg samples ranged from 0.027 to $1.056 \mu \mathrm{g} / \mathrm{g}$ with a mean value of $0.283 \mu \mathrm{g} / \mathrm{g} \pm 0.86$, whereas cadmium concentrations ranged from 0.001 to $0.012 \mu \mathrm{g} / \mathrm{g}$ with a mean value of $0.003 \mu \mathrm{g} / \mathrm{g} \pm 0.002$. Lead concentrations exceeded the normal levels of 0.020 but cadmium was found lower than the normal levels of $0.005 \mu \mathrm{g} / \mathrm{g}$.
\end{abstract}

Keywords: hen eggs, lead, cadmium, atomic absorption, spectrometry

\section{Introduction}

Fresh eggs are among the most important and common source of animal protein being the nutritious food of daily diet. Eggs are the source of protein, minerals and trace elements and unsaturated fatty acid which are necessary for proper development and functioning of different tissues and organs. In Pakistan consumption of egg per capita significantly increased during the last few years. On the other side, hen eggs contamination by potential toxic metals caused serious health hazards for public health as a source of metal exposure (Fakayode, 2003). Metals can be transferred from parent to offspring and can be sequestered from hen to eggs along the food chain when an animal is fed on metal contaminated feed (Meluzzi et al., 1996), through environmental contamination in the form of atmospheric deposition of metal from industry or vehicular emission (Mochizuki et al., 2002).

The rate of industrialization in urban areas particularly in big cities is increasing with the passage of time. Present level of urbanization in Pakistan is the highest in south Asia; Sindh is the most urbanized province and $60 \%$ of urban population of Sindh resides in Karachi

*Author for correspondence; E-mail: pcsirklc_ces@hotmail.com which is the largest industrial city of Sindh province. Landhi/Korangi Industrial Zone has a total area of 34.4 $\mathrm{km}^{2}$ having more then 2000 various types of small and medium sized industrial units of poultry and cattle farms (Mahmood et al., 1998). There are various types of environmental pollution due to indiscriminate discharge of industrial waste which constitute a potential danger to neighboring localities and pose many challenges related to food quality and safety (Abou Donia, 2008) with increasing industrializa-tion, more and more metals are entering into the environment. These metals stay permanently because they can not be degraded in the environment. They enter into the food matrix and from there they ultimately make their passage into animal tissues (Baykov et al., 1996).

Lead, cadmium, mercury and arsenic are among the main toxic metals which accumulate in food chains and have a cumulative effect. There are maximum levels for lead, cadmium and mercury in several foodstuffs such as meat, vegetable or fish nevertheless, no maximum levels exist for these trace elements in eggs (EC, 2006). Lead is ubiquitous in the environment persists indefinitely and can be found at low levels in almost all living organisms (Doganoc, 1996). Cadmium as environmental pollutant is well known to have a 
serious biological toxicity, and there have been many studies suggesting it to be the cause of "Itai-Itai disease" (Mochizuki et al., 2002). Lead is considered one of the major environmental pollutants, and the effect of lead $(\mathrm{Pb})$ on chicken, dove and wild animals is well documented (Dong-Ha et al., 2002).

Lead is one of the toxic metals; dangerous to most human body organs if exposure exceeds tolerable levels. It can affect individuals of any age, but it has a disproportionate effect on children as their behavioural patterns place them at higher risk for exposure to lead. Children bodies absorb a larger percentage of the lead that they ingest and exhibit lead toxicity at lower levels of exposure than adults (ATSDR, 1999). Accumulation of lead produces damaging effects in the hematopoetic, hematic, renal and gastrointestinal systems (Correia et al., 2000). Lead has been associated with various forms of cancer, nephro-toxicity, central nervous system and cardiovascular diseases in human (Pitot and Dragan, 1996). Toxicity of lead is closely related to age, sex, route of exposure, level of intake, solubility, metal oxidation state, retention percentage, duration of exposure, frequency of intake, absorption rate and mechanisms and efficiency of excretion (Mertz, 1986) and its inhalation may permanently lower intelligence quotient (IQ), damage emotional stability, cause hyperactivity, poor school performance and hearing loss (Goyer, 1996).

Lead ingested by chicken is deposited in bones, soft tissues and eggs and produces elevated blood lead levels (Bakalli et al., 1995). The highest concentration of lead in egg is due to accumulation of lead in their shells, yolk and albumin (Trampel et al., 2003). Lead is considered one of the major environmental contaminant (unique among metals) because of its toxic effects, extremely protected biological half life, low rate of extraction from the body and predominant storage in soft tissue (Skalicka et al., 2008).

Lead can be very harmful even at low concentrations when ingested over a long time. After ingestion, the absorption rate of lead ranges from 3 to $80 \%$, whereas the typical absorption rates of dietary lead in adults and infants are $10 \%$ and $50 \%$, respectively. After absorption, lead is initially distributed to soft tissues throughout the body via blood, and then deposited in bone (Celik and Oehlenschlager, 2004). Lead is excreted through the kidney and to a lesser extent in the bile while non-absorbed dietary lead is excreted in the feces.
Cadmium is a nonessential nutrient that is of direct concern to human, livestock and poultry health and may accumulate in the body, particularly in the kidney liver and to a lesser extent in the muscles (Mecrory et al., 2005). Most of us ingest trace metals via food in our daily diets, although the quantity of trace metals varies from place to place, depending on the dietary habits and level of environmental pollution (Shahidul Islam et al., 2007).

Cadmium is a highly reactive and toxic element, which is sparsely distributed in most agricultural ecosystems. Once absorbed by animals or humans, however, cadmium is poorly excreted, and increased efforts are being made to limit the entry of cadmium into the human food-chain (Underwood and Suttle, 1999). The maximum residual limit of cadmium in broiler chicken diets is $0.5 \mathrm{mg} / \mathrm{kg}$ (Herzig et al., 2007).

The toxicity of cadmium affects many target tissues such as appetite and pain centres (in brain), brain, heart and blood vessels, kidneys and lungs. This toxicity may cause anemia, dry and scaly skin, emphysema, fatigue, hair loss, heart disease, depressed immune system response, loss of sense of smell, lung cancer, pain in the back and legs and yellow teeth in humans (Kocak et al., 2005).

Cadmium is found in low amounts in the soil. It is transported via air and water from intensive industrial regions to the soil and sea and is considered to be the most important contaminant in modern times. Cadmium derives its toxicological properties from its chemical similarity to zinc, and essential micronutrient from plants, animals and humans. Toxic contents of this element lead to renal insufficiency and metabolic abnormalities via enzyme inhibition (Hura, 2002).

Toxic effects of cadmium are seen on kidney dysfunction, hypertension, hepatic injury and long damage (Akan et al., 2010). The uptake of lead from eggs in children is approximately $40 \%$ (Chiy and Philips, 1997). Daily intake of metals through the chicken eggs in different countries is summarized in Table 1.

The present study has been done by sampling of a number of eggs from different poultry farms of Sindh in Pakistan for analysis of lead and cadmium.

\section{Materials and Methods}

Sampling. This study was carried out in Karachi region during the period 2004-2007. A total of 54 hen's eggs 
were obtained from nine poultry farms in different batches.

Reagents. All reagents were ultra pure of analyticalreagent grade. All aqueous solutions were prepared with deionized water, use for preparation and dilution of reagents and standards, were prepared by passing tap water through cellulose absorbent and 2 mix bed ionexchange columns. The deionized water was then double distilled in a caring all glass unit. Reference standards were prepared from Accus Trace Reference Standards (1000 ppm) USA.

Analytical procedure. Each egg was broken separately and the yolk and egg white were mixed. Accurately 2-5 g mixed sample was taken in triplicate of each representative sample into a $250 \mathrm{~mL}$ Pyrex beaker. Then, $10 \mathrm{~mL}$ volume of a concentrated $\mathrm{HNO}_{3}(65 \%)$ and $5 \mathrm{~mL}$ of $\mathrm{H}_{2} \mathrm{O}_{2}$ were added to each flask and solutions were heated on electric hot plate at $80^{\circ} \mathrm{C}$ for $2-3 \mathrm{~h}$, until the clear transparent solutions were obtained. Finally the solutions were made up to $50 \mathrm{~mL}$ of volumetric flask. After homogenization and agitation of organic matter, $25 \mathrm{~mL}$ of egg sample was destroyed by wet digestion with $\mathrm{HNO}_{3}$ on a sand bath up to complete digestion. After mineralization, the samples were brought to a volume of $50 \mathrm{~mL}$ with de-ionized water. Blanks were carried out during the process of organic matter destruction to assess the absence of contamination.

Prepared samples were subjected to electrothermal atomic absorption spectrophotometer (ETAAS) for estimation of $\mathrm{Pb}$ and $\mathrm{Cd}$. Calibration curves for $\mathrm{Pb}$ and $\mathrm{Cd}$ are presented in Figs. 1-2. Blank digestions (without analyte) were also carried out.

Instrumentation. Electro thermal atomic absorption spectroscopy is the technique most often applied to

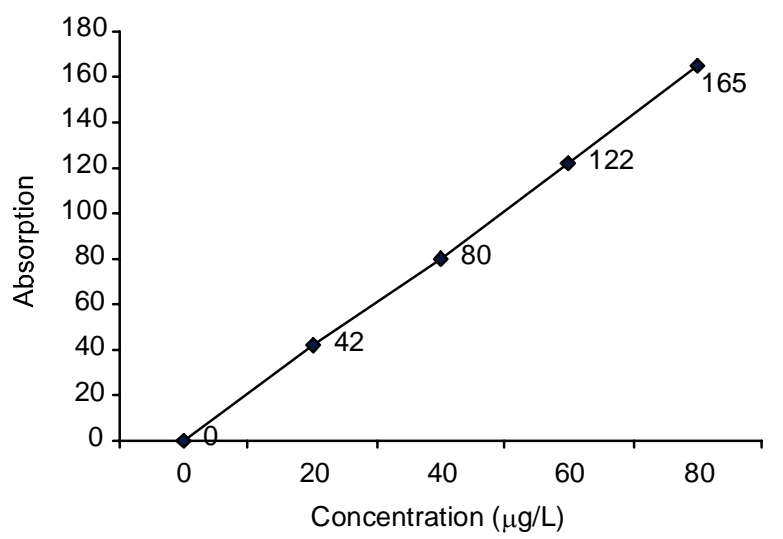

Fig. 1.Calibration curve for $\mathrm{Pb}$.

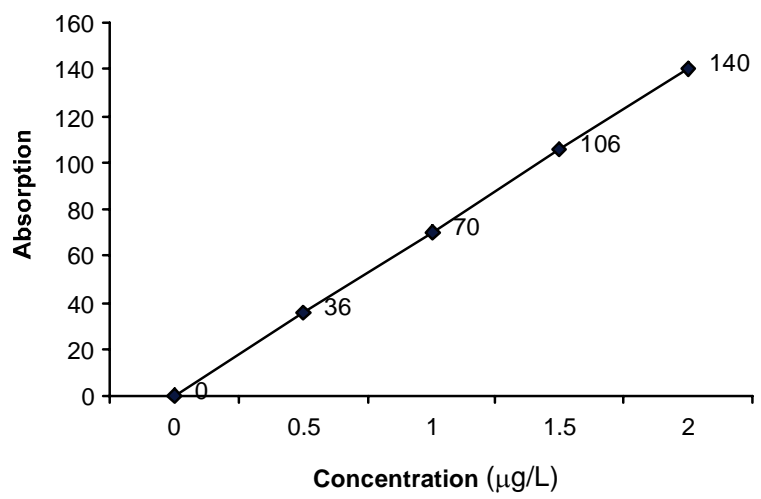

Fig. 2.Calibration curve for $\mathrm{Cd}$.

determine lead in foods either after a dry or wet destruction of the organic matter.

All atomic absorption measurements were carried out with Hitachi atomic absorption spectrophotometer Z8000 with Zeeman back ground correction equipped with a graphite furnace, microprocessor and a built in printer, was used for the determination of the concentration of metals in the samples. $\mathrm{Pb}$ and $\mathrm{Cd}$ were

Table 1. Instrumental conditions for the determination of Lead $(\mathrm{Pb})$ and Cadmium (Cd)

\begin{tabular}{llllll}
\hline \hline Metals & $\begin{array}{l}\text { Wavelength } \\
(\mathrm{mm})\end{array}$ & $\begin{array}{l}\text { Slit } \\
(\mathrm{mm})\end{array}$ & State & $\begin{array}{l}\text { Temperature } \\
\left({ }^{\circ} \mathrm{C}\right)\end{array}$ & $\begin{array}{l}\text { T i m e } \\
(\mathrm{sec})\end{array}$ \\
\hline Lead & 283.3 & 1.3 & Drying & $80-120$ & 30 \\
& & Ashing & $400-400$ & 30 \\
& & Atomizing & $2000-2000$ & 10 \\
& & & Cleaning & $2400-2400$ & 3 \\
Cadmium & \multirow{2}{*}{1.3} & Drying & $80-120$ & 30 \\
& 228.8 & & Ashing & $300-300$ & 30 \\
& & Atomizing & $1500-1500$ & 10 \\
& & Cleaning & $1800-1800$ & 3 \\
\hline \hline
\end{tabular}


analyzed by flameless (ETASS) atomic absorption spectrophotometer.

A $20 \mu \mathrm{L}$ volume sample solution was injected by Eppendroff pippet. Single element hollow cathode lamps of analytes were used as radiation source. Operating parameters of analytes were set as recommended by the manufacturer. Hitachi graphite platform inserted into pyrolytically coated tubes were used to measure all absorbance values by using integrated mode. Argon was used a carried gas during all the stages except for atomization. Optimized graphite furnace temperature programmed, for the determination of $\mathrm{Pb}$ and $\mathrm{Cd}$ by ETAAS is presented in Table 1.

Statistical analysis. Statistical calculations were performed using computer program Minitab 13.2 (Minitab Inc., State College, PA) and Excel Table 2 and 3.

Quality control. According to a t-test, all determined and spiking values are in good agreement at a $95 \%$ confidence level with the reference materials for the reliability of the method.

Recovery for Pb and Cd. Recovery of hen egg samples was determined by spiking method. For recovery, test egg sample was spiked with the known amount of standards for $\mathrm{Pb}$ and $\mathrm{Cd}$ as presented in Table 4 .

Table 2. Correlation coefficient among the metals content found in egg samples

\begin{tabular}{lll}
\hline \hline Metals & $\mathrm{Cd}$ & $\mathrm{Pb}$ \\
\hline $\mathrm{Cd}$ & 1.000 & - \\
$\mathrm{Pb}$ & 0.192 & 1.000 \\
\hline
\end{tabular}

Table 3. Overall summary of the metal contents

\begin{tabular}{lll}
\hline \hline & $\mathrm{Pb}$ & $\mathrm{Cd}$ \\
\hline Mean & 11.88 & 37.68 \\
$\mathrm{SD}$ & 6.88 & 10.20 \\
Median & 10.84 & 39 \\
Mode & 11.32 & 41 \\
Minimum & 3.59 & 22 \\
Maximum & 44.12 & 73 \\
Confidence & 2.22 & 3.29 \\
Variance & 47.40 & 104.06 \\
\hline \hline
\end{tabular}

Table 4. Recovery for $\mathrm{Pb}$ and $\mathrm{Cd}$ determined in egg

\begin{tabular}{|c|c|c|c|c|}
\hline Metals & $\begin{array}{l}\text { Spike level } \\
(\mu \mathrm{g} / \mathrm{mL})\end{array}$ & $\begin{array}{l}\text { Number of } \\
\text { Samples }\end{array}$ & $\begin{array}{l}\text { Recovery } \\
\text { (\%) }\end{array}$ & $\begin{array}{l}\text { Paired t-test } \\
\mathrm{T} \text { experimental } \\
2.580\end{array}$ \\
\hline \multirow[t]{3}{*}{ Lead } & 0.2 & 10 & 98.1 & 1.40 \\
\hline & 0.4 & 10 & 98.9 & 2.00 \\
\hline & 0.8 & 10 & 98.9 & 2.00 \\
\hline \multirow[t]{3}{*}{ Cadmium } & 0.2 & 10 & 99.1 & 1.50 \\
\hline & 0.4 & 10 & 99.3 & 1.87 \\
\hline & 0.8 & 10 & 99.1 & 1.98 \\
\hline
\end{tabular}

*Paired t-test critical at 95\% confidence limit $=2.580$

The significance of the effects was evaluated with the ttest (t of Student). Experimental values were calculated at degree of freedom $\mathrm{n}-1=9$, the experimental values were found lower than the critical (2.58, at a $95 \%$ of confidence level), indicating non significant difference were observed in obtained values of non essential elements.

\section{Results and Discussion}

The study was carried out for 54 egg samples collected from nine poultry farms of Karachi. Samples were collected during the year 2004-2007. Analysis of hen egg samples were carried out for lead and cadmium by using AAS.

Results of 54 hen egg samples in the form of minimum, maximum, average and Standard deviation are presented in Table 5. Minimum and maximum concentrations of lead and cadmium for each of nine poultry farms are presented in Table 6. The level of concentration of lead and cadmium were found in $\mu \mathrm{g} / \mathrm{g}$.

The presence of lead in the environment is partially due to natural sources and anthropogenic sources (Beavington et al., 2004; Fernandez et al., 2000), whereas mostly due to the industrial waste emission (Al-Masri et al., 2006; Khillare et al., 2004). According to the Food and Drug Administration (FDA), food and feed crops provide approximately 34 to $44 \%$ of dietary intake of $\mathrm{Pb}$ (Cabrera et al., 1994). Animals like poultry chicken that have stored appreciable amount of lead and cadmium may transfer these elements to human when ingested.

The result suggested that total average maximum concentration of lead in 54 hen eggs samples was found to be $1.0557 \mu \mathrm{g} / \mathrm{g}$ and minimum was found to be $0.0269 \mu \mathrm{g} / \mathrm{g}$, whereas total average concentration of 54 samples was found to be $0.2830 \mu \mathrm{g} / \mathrm{g}$ (Table 5). 
Table 5. Concentration range as minimum, maximum, average mean, median and standard deviation values of $\mathrm{Pb}$ and $\mathrm{Cd}$ from 54 hen egg samples

\begin{tabular}{llllll}
\hline \hline Metals & Maximum & Minimum & Average mean & Median & Standard deviation \\
\cline { 2 - 5 } & & $(\mu \mathrm{g} / \mathrm{g})$ & \\
\hline $\mathrm{Pb}$ & 1.0557 & 0.0269 & 0.2830 & 0.1827 & 0.2427 \\
$\mathrm{Cd}$ & 0.0122 & 0.0010 & 0.0032 & 0.0026 & 0.0020 \\
\hline \hline
\end{tabular}

The highest lead concentration $1.0557 \mu \mathrm{g} / \mathrm{g}$ was found in the samples of Farm No. 3 and the lowest concentration $0.0269 \mu \mathrm{g} / \mathrm{g}$ in hen egg sample was found in Farm No. 7. (Table 6).

The factor responsible for tremendous increase in lead in Farm No. 3 may be due to environmental contaminants with largely air born sources such as combustion of fuel containing lead additives and industrial emission including smelters. Industrial smoke, stack and automobiles emissions are the most common sources of lead and cadmium in the environment.

The presence of cadmium in food items could be due to the excessive use of inorganic or organic fertilizer which may lead to the accumulation of metals in the soil which would be biomagnified by plants and eventually in animal feed (Chiy and Philips, 1997; Gary et al., 1999; Grant and Bailey, 1997; McLaughlin et al., 1995). Intrusion of metals during the grinding or milling process might contribute to the higher concentration of cadmium in feed. Grain such as maize, soya bean and wheat, the major components of feed, could also have picked up or bio-accumulated cadmium directly from contaminated soil, depending on the location on which they were grown and also on the chemical nature of the soil.

Total average maximum concentration of cadmium in 54 hen egg samples was found to be $0.0122 \mu \mathrm{g} / \mathrm{g}$ and minimum was found to be $0.001 \mu \mathrm{g} / \mathrm{g}$, where as total average concentration was found to be $0.0032 \mu \mathrm{g} / \mathrm{g}$ (Table 5). The highest concentration of cadmium $0.0122 \mu \mathrm{g} / \mathrm{g}$ was also found in the samples of farm No. 3, where as lowest concentration $0.0010 \mu \mathrm{g} / \mathrm{g}$ in hen egg sample was found to be in farm No. 4 (Table 6). The most important factor which increases the level of cadmium contamination in the environment may be the atmospheric pollution from industrial and motor vehicle emission.

Many studies on toxic metal concentration in hen eggs have been undertaken in various countries (Table 7), it shows that in the present study average concentration
Table 6. Minimum and maximum values of $\mathrm{Pb}$ and $\mathrm{Cd}$ from nine poultry farms

\begin{tabular}{llll}
\hline \hline Metals & Farm no. & $\begin{array}{l}\text { Minimum } \\
(\mu \mathrm{g} / \mathrm{g})\end{array}$ & $\begin{array}{l}\text { Maximum } \\
(\mu \mathrm{g} / \mathrm{g})\end{array}$ \\
\hline Lead $(\mathrm{Pb})$ & 1 & 0.1795 & 0.4736 \\
& 2 & 0.2333 & 0.8636 \\
& 3 & 0.4701 & 1.0557 \\
& 4 & 0.0896 & 0.2882 \\
& 5 & 0.0466 & 0.2710 \\
& 6 & 0.1279 & 0.1853 \\
& 7 & 0.0269 & 0.1557 \\
& 8 & 0.1263 & 0.6202 \\
& 9 & 0.0412 & 0.1182 \\
& 1 & 0.0027 & 0.0062 \\
& 2 & 0.0018 & 0.0043 \\
& 3 & 0.0046 & 0.0122 \\
& 4 & 0.0010 & 0.0036 \\
& 5 & 0.0014 & 0.0037 \\
6 & 0.0021 & 0.0026 \\
7 & 0.0011 & 0.0022 \\
& 7 & 0.0018 & 0.0034 \\
9 & 0.0412 & 0.1182 \\
\hline \hline
\end{tabular}

of lead from 54 hen eggs samples was recorded in the range of $0.0269 \mu \mathrm{g} / \mathrm{g}$ to $1.0557 \mu \mathrm{g} / \mathrm{g}$ with the mean value of $0.2830 \mu \mathrm{g} / \mathrm{g}$ (Table 5). The mean average value $(0.2830 \mu \mathrm{g} / \mathrm{g})$ of lead was found to be higher than the average value of $69 \mu \mathrm{g} / \mathrm{kg}$ in home produced egg in Belgium (Waegeneers et al., 2009), $0.01 \mu \mathrm{g} / \mathrm{g}$ reported from Canada (Kirkpatrick and Coffin, 2006), $0.048 \mu \mathrm{g} / \mathrm{g}$ reported from China (Fakayode, 2003) and $0.59 \mu \mathrm{g} / \mathrm{g}$ found to be lower reported from Nigeria (Fakayode, 2003), India $0.489 \mu \mathrm{g} / \mathrm{g}$ (Dey and Dwivedi, 2000), France $11 \mu \mathrm{g} / \mathrm{g}$ (Leblance et al., 2005), Denmark <5 $\mu \mathrm{g} / \mathrm{g}$ (Larsen et al., 2002) and $3 \mu \mathrm{g} / \mathrm{g}$ from diet study in UK (Ysart et al., 2000).

Whereas the mean average concentration of cadmium from 54 hen eggs samples was found to be $0.0032 \mu \mathrm{g} / \mathrm{g}$ which is lower than reported in hen eggs in Canada 
Table 7. Toxic metal concentration in hen egg samples reported in various countries

\begin{tabular}{llll}
\hline \hline Country & $\begin{array}{l}\mathrm{Pb} \\
(\mu \mathrm{g} / \mathrm{g})\end{array}$ & $\begin{array}{l}\mathrm{Cd} \\
(\mu \mathrm{g} / \mathrm{g})\end{array}$ & References \\
\hline Canada & 0.01 & 0.01 & Kirkpatrick and Coffin, 2006 \\
Finland & - & 0.004 & Fakayode, 2003 \\
China & 0.048 & 0.005 & Fakayode, 2003 \\
Nigeria & 0.59 & 0.07 & Fakayode, 2003 \\
India & 0.489 & 0.072 & Dey and Dwivedi 2000 \\
Belgium & 69 & 0.53 & Waegeneers et al., 2009 \\
France & 11 & 0.4 & Leblance et al., 2005 \\
Denmark & $<5$ & $<0.6$ & Leblance et al., 2005 \\
UK & 3 & 0.4 & Ysart et al., 2000 \\
\hline \hline
\end{tabular}

(0.01 $\mu \mathrm{g} / \mathrm{g}$, Kirkpatrick and Coffin, 2006), Finland $(0.004 \mu \mathrm{g} / \mathrm{g})$, China $(0.005 \mu \mathrm{g} / \mathrm{g})$ and Nigeria (0.07 $\mu \mathrm{g} / \mathrm{g}$, Fakayode, 2003), India $0.072 \mu \mathrm{g} / \mathrm{g}$ (Dey and Dwivedi, 2000), Belgium $0.53 \mu \mathrm{g} / \mathrm{g}$ (Waegeneers et al., 2009), France $0.4 \mu \mathrm{g} / \mathrm{g}$ (Leblance et al., 2005), Denmark $<0.6 \mu \mathrm{g} / \mathrm{g}$ (Larsen et al., 2002) and $0.4 \mu \mathrm{g} / \mathrm{g}$ from diet study in UK (Ysart et al., 2000).

Table 2 presents the matrix correlation coefficient which determines the behavior of two related variables and the extent of their relation denoted by "R". Table 2 clearly shows that values are positive and approximately values are above 0.2 .

The average estimated daily intake of lead from egg in Karachi, Pakistan is $8.91 \mu \mathrm{g} /$ person, significantly higher than the daily intake of $\mathrm{Pb}$ from eggs of $0.3,5.1$ and $6.1 \mu \mathrm{g} /$ person reported from Finland, Germany and Japan, respectively and lower than in Nigeria of $19.5 \mu \mathrm{g} /$ person. The average estimated daily intake of $\mathrm{Cd}$ of $0.09 \mu \mathrm{g} /$ person was found to be lower than that of $2.4 \mu \mathrm{g}, 0.6 \mu \mathrm{g}$, $0.5 \mu \mathrm{g}$ and $0.1 \mu \mathrm{g}$ of Cd from the eggs reported for Nigeria, Finland, Germany and Japan, respectively (Fakyode, 2003). EC has not mentioned the daily intake value of lead and cadmium with reference to egg.

A provisional tolerable weekly intake (PTWI) value for lead has been established at $25 \mu \mathrm{g} / \mathrm{kg}$ body weight (FAO/WHO, 1993). PTWI value for cadmium has been established at $7 \mu \mathrm{g} / \mathrm{kg}$ of body weight (FAO/WHO, 1989).

\section{Conclusion}

The amounts of lead $(\mathrm{Pb})$ and cadmium $(\mathrm{Cd})$ in eggs is particularly call for serious attention. Considering the gravity and intensity of danger that lead $(\mathrm{Pb})$ and cadmium (Cd) could present to public health and safety, the monitoring and regulation of these and other toxic metals in eggs, animal feeds, and other food items must be given proper attention by the food regulatory body and by the appropriate authority for meeting the standards for concentrations of heavy metals that have been attained in more-developed countries.

\section{References}

Abou Donia, M.A. 2008. Lead concentrations in different animal muscles and consumable organs at specific localities in Cario. Global Veterinaria, 2: 280-284.

Akan, J.C., Abdulrahman, F.I., Sodipo, O.A., Chiroma, Y.A., 2010. Distribution of heavy metal in the liver, kidney and meat of beef, mutton, caprine and chicken from Kasuwan Shanu market in Maduguri metropolis, Borno State, Nigeria. Research Journal of Applied Sciences, Engineering and Technology, 2: 743-748.

Al-Masri, M.S., Al-Kharfan, K., Al-Shamali, K. Al. 2006. Speciation of $\mathrm{Pb}$, $\mathrm{Cu}$ and $\mathrm{Zn}$ determined by sequential extraction for identification of air pollution sources in Syria. Atmospheric Environment, 40: 753-761.

ATSDR. 1999. Toxicological Profile for Lead, Agency for Toxic Substance and Disease Registry, US Department of Health and Human Services, Atlanta, GA, USA.

Bakalli, R.I., Pesti, G.M., Ragland, W.L. 1995. The magnitude of lead toxicity in broiler chickens. Veterinary and Human Toxicology, 37: 15-19.

Baykov, B.D., Stoyanov, M.P., Gugova, M.L. 1996. Cadmium and lead bioaccumulation in male chickens for high food concentrations. Toxicological and Environmental Chemistry, 54: 155-159.

Beavington, F., Cawes, P.A., Wakenshaw, A. 2004. Comparative studies of atmospheric trace element: improvement in air quality near copper smelters. Science of the Total Environment, 332: 39-49.

Cabrera, C., Callego, M., Lopez, C., Lorenza, M.I. 1994. Determination of level of lead contamination in food and feed crops. Journal of AOAC International, 77: 1249-1252.

Celik, U., Oehlenschlager, J. 2004. Determination of zinc and copper in fish samples collected from Northeast Atlantic by DPSAV. Food Chemistry, 87: 343-347.

Chiy, P.C., Philips, C.J.C. 1997. Effects of sodium fertilizers on the chemical composition of perennial ryegrass and white clover leaves of different physiological ages. Journal of the Science of Food and Agriculture, 73: 337-348. 
Corriea, P.R.M., Oliveria, E., Oliveria, P.V. 2000. Simultaneous determination of $\mathrm{Cd}$ and $\mathrm{Pb}$ in food stuffs by electro thermal atomic absorption spectrometry. Analytical Chimica Acta, 405: 205-211.

Dey, S., Dwivedi, S.K. 2000. Toxic metals in hen's egg in India. A preliminary report. Archives of Environmental Health, 55: 365-368.

Doganoc, D.Z. 1996. Distribution of lead, cadmium and zinc in tissues of hens and chickens from Slovenia. Bulletin Environmental Contamination and Toxicology, 57: 932-937.

Dong-Ha, N., Doo-Pyo, L., Tea-hoe, K. 2002. Comparison of heavy metal concentration and reproduction of feral pigeons (Columba livia) between urban and industrial complex areas from Korea. Korean Journal of Ecological Science, 1: 159-164.

EC. 2006. Commission Regulation (EC) No. 1881/2006 of 19 December 2006. Setting maximum levels for certain contaminants in foodstuffs. Official Journal of the European Union, 2006; L364/5.

Fakayode, S.O. 2003. Trace metal content and estimated daily human intake from chicken eggs in Ibadan, Nigeria. Environmental Health, 58: 245-251.

FAO/WHO. 1993. Evaluation of Certain Food Additives and Contaminants, WHO Technical Report Series, 837, Geneva, Switzerland.

FAO/WHO, 1989. Toxicological Evaluation of Certain Food Additives and Contaminants, WHO Food Additive Series, 24, Geneva, Switzerland.

Fernandez, A.G., Ternero, M., Barragan, G.F. 2000. An approach to characterization of sources of urban air born particle through heavy metal speciation. Chemosphere, 2: 123-136.

Goyer, R.A. 1996. Results of lead research: prenatal exposure and neurological consequences. Environmental Health Perspectives, 104: 1050-1054.

Grant, C. A., Bailey L.D. 1997. Effects of phosphorus and zinc management on cadmium accumulation in flax seed. Journal of the Science of Food and Agriculture, 73: 307-314.

Gary, C.W., Mclaren, R.G., Robert, A.H.C. 1999. The effect of ion-term phosphatic fertilizer application on the amount and forms of cadmium in soil under pasture in Newzealand. Nutrent Cycling in Agroecosystems, 54: 267-277.

Herzig, I., Navratilova, M., Suchy, P., Vecerek, V., Totusek, J. 2007. Model trial investigation retention in selected tissues using broiler chicken fed cadmium and humic acid. Veterinarians Medicine, 52: 162-168.
Hura, C. 2002. Chemical Contaminants in Food and Human Body: 1990-2000. Cermi Press, Lasi, ISBN 973-8188, 1-6.

Khillare, P.S., Balachandaran, S., Meena, B.R. 2004. Spatial and temporal variation of heavy metal in atmospheric aerosol of Delhi. Environmental Monitoring and Assessment, 90: 1-21.

Kirkpatrick, D.C., Coffin, E.D. 2006. Trace metal content of chicken eggs. Journal of the Science of Food and Agriculture, 8: 245-251.

Kocak, S., Tokusoglu, O., Aycan, S. 2005. Some heavy metals and trace essential elements detection in canned vegetable food stuff by differential pulse paleography. Electronic Journal of Environmental Agricultural and Food Chemistry, 4: 871-878.

Larsen, E.H., Andersen, N.L., Moller, A., Petersen, A., Mortensen, G.K., Petersen, J. 2002. Monitoring of the content and intake of trace elements from food in Denmark. Food Additives and Contaminants, 19: 33-46.

Leblance, J.C., Guerin, T., Noel, L., Calamassi-Tran, G., Volatier, J.L., Verger, P. 2005. Dietary exposure estimation of 18 elements from the $1^{\text {st }}$ French total diet study, Food Additives and Contaminants, 22: 624-641.

Mahmood, N.S., Sitwat, N., Ishratullah, S., Farooq, A.K. 1998. Metal contamination in ground water of Korangi Industrial Area, Karachi. Journal of Chemical Society of Pakistan, 20: 125-131.

McLaughlin, M.J., Maier, N.A., Freeman, K. Tiller, K.G., Williams, C.M.J., Smart, M.K. 1995. Effect of potassic and phosphatic fertilizer type, fertilizer cadmium concentration and zinc rate on cadmium uptake by potatoes. Fert Research, 40: 63-70.

Mecrory, Y.L., Powell, D.F., Seem, J.M., Smith, J.H. 2005. A survey of selected heavy metal concentrations in Wisconsin dairy feeds. Journal of Dairy Science, 88: 2911-2922.

Meluzzi, A., Simoncini, F., Sirri, F. 1996. Feeding hens diets supplemented with heavy metals ( $\mathrm{Cr}, \mathrm{Ni}$ and $\mathrm{Pb})$. Arch Geflugelkunde, 3: 119-125.

Mertz, W.E.D. 1986. Trace Elements in Human and Animal Nutrition, vol. I and II, $5^{\text {th }}$ edition, Academic Press, London, UK.

Mochizuki, M., Honndo, R., Kumon, K., Sasaki, R., Matsuba, H., Ueda, F. 2002. Cadmium contamination in wild birds as an indicator of environmental pollution. Environmental Monitoring and Assessment, 73: 229-235.

Pitot, C.H., Dragan, P.Y. 1996. Chemical Carcinogenesis. 
Casarett and Doull's Toxicology, pp. 201-260, $5^{\text {th }}$ edition, International edition. McGraw Hill, New York, USA.

Shahidul Islam, M., Aziz ul Islam, K.M., Hossain, M.M., Ahsan, A.M., Maruf Hossain, A.M.M. 2007. Propagation of heavy metals in poultry feed production in Bangladesh. Bangladesh Journal of Scientific and Industrial Research, 42: 465-474.

Skalicka, M., Korenekova, B., Nad, P. 2008. Distribution of trace elements in liver and muscle of Japanese quails. Slovak Journal of Animal Science, 41: 187-189.

Trampel, D.W., Imerman, P.M., Carson, T.L., Kinker, J.A., Ensley, S.M. 2003. Lead contamination of chicken eggs and tissues from a small farm flock.
Journal of Veterinary Diagnostic Investigation, 15: 418-422.

Underwood, E.J., Suttle, N.F. 1999. The Mineral Nutrition of Livestock. $3^{\text {rd }}$ edition. CAB Publishing, New York, USA.

Waegeneers, N., Hoenig, M., Goeyens, L., Temmerman, L.D. 2009. Trace elements in home-produced eggs in Belgium. Levels and spatio temporal distribution. Science of Total Environment, 407: 4397-4402. Ysart, G., Miller, P., Croasdale, M., Crews, H., Robb, P., Bxter, M., Argy, de L.C., Harrison, N. 2000. Total diet study-dietary exposures to aluminium, arsenic, cadmium, chromium, copper, lead, mercury, nikel, selenium, tin and zinc. Food Additives and Contaminants, 17: 775-786. 